\title{
Summer diet of the Iberian chub (Squalius pyrenaicus) in a Mediterranean stream in Sierra Morena (Yeguas stream, Córdoba, Spain).
}

\author{
F. Blanco-Garrido ${ }^{1}$, F.J. Sánchez-Polaina ${ }^{2}$ and J. Prenda ${ }^{1}$
}

${ }^{1}$ Departamento de Biología Ambiental y Salud Pública, Universidad de Huelva. Campus universitario de El Carmen, Avda. de la Fuerzas Armadas s/n, 21007 Huelva. E-mail: jprenda@uhu.es.

2 Departamento de Medio Ambiente y Protección Civil. Diputación de Córdoba. Avda. Mediterráneo s/n, 14071 Córdoba. E-mail: fsanchezp@dipucordoba.es

\begin{abstract}
The summer diet of the Iberian chub (Squalius pyrenaicus) was studied in the upper Yeguas river (Córdoba, Spain). The chub showed a wide trophic range, and a pronounced generalist character. The main trophic categories were chironomid larvae and filamentous algae. Mean prey size consumed was positively correlated with fish furcal length and mouth size, and no relation was found between mean prey size and sex. No differences were detected in diet composition between males and females. However, differences in gut length and diet diversity was observed between sexes; mean values being higher for females than males in both cases, despite that no significant differences in body size have been observed between sexes. The higher trophic diversity and gut length in females could be interpreted as a mechanism to reduce the possible competition between sexes and/or to ensure access to trophic resources in summer, the most critical period of the year. Moreover, diet shifts were observed during ontogeny.

The generalist diet of the chub, the differences observed between the diet of sexes and the ontogenetic diet shifts may be important adaptation features in the exploitation of the fluctuating Mediterranean freshwater habitats.
\end{abstract}

Keywords: Squalius pyrenaicus, feeding ecology, diet shift, Mediterranean streams.

\section{RESUMEN}

La dieta estival del cachuelo (Squalius pyrenaicus) se ha estudiado en el curso alto del río Yeguas (Córdoba). El cachuelo presentó un amplio espectro trófico y un marcado carácter generalista. Las categorías tróficas más importantes fueron larvas de quironómidos y algas filamentosas. El tamaño medio de las presas consumidas estuvo positivamente correlacionado tanto con la longitud furcal como con la abertura bucal y fue independiente del sexo. No se han detectado diferencias en la composición de la dieta entre machos y hembras. Sí se encontraron en cambio, diferencias en la longitud del tracto digestivo y en la diversidad de la dieta entre sexos, siendo en ambos casos los valores medios superiores en hembras que en machos, a pesar de no haberse observado diferencias significativas en el tamaño de los sexos. La mayor diversidad trófica y la mayor elongación intestinal en las hembras pueden ser interpretadas como un mecanismo tendente a reducir la posible competencia entre sexos y/o garantizar el aporte trófico en el período más crítico del año (verano). Además, se han observado cambios ontogenéticos en la alimentación.

La alimentación generalista del cachuelo, las diferencias observadas entre las dietas de machos y hembras y los cambios ontogenéticos en su alimentación pueden ser adaptaciones importantes en la explotación de los fluctuantes hábitats acuáticos mediterráneos.

Palabras clave: Squalius pyrenaicus, alimentación, cambios en la dieta, ríos mediterráneos.

\section{INTRODUCTION}

One of the most basic questions in fish ecology is to know fishes' diets. Diet analysis of fishes allow us to interpret their feeding strategy, their intra- or interspecific potential interactions (competition and predation) and their foraging behaviour. This is especially important 
in Mediterranean streams subjected to high environmental fluctuations and strong summer drought, which reduces streams to a succession of unconnected pools. Under this circumstances fishes are confined to small areas (pools) and usually at considerably high densities (Pires et al., 1999) where biotic interactions such as competition for food resources could become temporally important (Cowx et al., 1984; Matthews, 1988).

The Iberian chub (Squalius pyrenaicus) is an Iberian endemism and one of the most common cyprinid fishes, showing a wide range of geographical distribution. It appears in the central and southern catchments of the Iberian Peninsula (Doadrio, 2001), inhabiting all sort of flowing waters. Most published works on Iberian chub are based on biometry, life history analyses (Fernández-Delgado \& Herrera, 1995; LobónCerviá, 1982; Lobón-Cerviá \& Sostoa, 1987; Rodriguez, 1989), or are mere descriptions of the diet (Rodriguez-Jiménez, 1987; Encina \& Granado-Lorencio, 1991). Only a few studies deal with other aspects of the trophic ecology related to sex differences in diet or ontogenetic diet shift (e.g. Magalhães, 1993a).

The aim of this paper is to analyse the diet composition of Iberian chub during summer, the most critical period of the year, in relation to food and habitat availability in Mediterranean streams (Magalhães, 1993a, b) and to describe sex and size-related patterns of food resource utilization. These two points are essential to understand chub life history and intraspecific interactions during periods of food shortage.

\section{MATERIAL AND METHODS}

Fishes from upper Yeguas stream (Guadalquivir basin, Córdoba province, Spain) were sampled in July 1988 by electro-fishing. A total of 37 individuals of Iberian chub (Squalius pyrenaicus) were captured, 18 males and 19 females (Table 1), with fork length between 73-125 mm. Electro-fishing is a non-selective method that allows quick captures and avoids partial digestions of the prey. Moreover, electro-fishing prevents regurgitation (Windel \& Bowen, 1978).

The individuals were conserved in $4 \%$ formalin and transported to the laboratory where the following biometrical measures were recorded: fork length (FL, mm), weight (W, $0.1 \mathrm{~g})$ and mouth aperture (MA, $0.01 \mathrm{~mm}$ ). Complete guts were extracted and measured (GL, mm) from each specimen. Guts were preserved in ethanol $70 \%$ and washed with $\mathrm{KOH} \mathrm{5 \%}$ (Bellido et al, 1989). Sex was determined by direct observation.

Although prey determination was carried out at the lowest taxonomic level possible, the results were expressed by grouping them into the following categories: Algae, Phanerogamae, Atyaephyra desmaresti, Ostracoda, Acarina, Ephemeroptera, Odonata, Trichoptera, Heteroptera, Coleoptera larvae, Coleoptera (adults), Chironomidae larvae, chironomidae pupae, other Dipteran larvae, and fish.

Plant material and detritus were dried at $80{ }^{\circ} \mathrm{C}$ for 24 hours to obtain constant weight.

At the same time the fishes were captured, the macroinvertebrate community was sampled to: 1 ) obtain dry weight and estimate the biomass (dry weight) of the gut contents by extrapolation; and

Table 1. Differences among mean values of biometrical measures of Iberian chub (S. pyrenaicus) between sexes: LF, fork lenght (mm); W, fresh weight (g); MA, mouth aperture ( $\mathrm{mm})$; GL, gut length $(\mathrm{mm})$. Diferencias entre sexos de los valores medios de las medidas biométricas tomadas a los cachuelos (S. pyrenaicus): FL, longitud furcal (mm); W, peso fresco (g); MA, abertura bucal (mm); GL, longitud del tubo digestivo (mm).

\begin{tabular}{lcccc}
\hline & $\begin{array}{c}\mathbf{X} \pm \text { SD males } \\
(\mathbf{n}=\mathbf{1 8})\end{array}$ & $\begin{array}{c}\mathbf{X} \pm \text { SD females } \\
(\mathbf{n}=\mathbf{1 9 )}\end{array}$ & t-Student & ANCOVA \\
\hline FL & $87.11 \pm 11.05$ & $92.63 \pm 15.24$ & $\mathrm{t}=1.25$ & 0.21 \\
W & $11.81 \pm 4.56$ & $14.91 \pm 8.20$ & $\mathrm{t}=1.41$ & 0.16 \\
MA & $5.28 \pm 0.72$ & $5.81 \pm 1.35$ & $\mathrm{t}=1.35$ & \\
GL & $69.50 \pm 10.35$ & $78.95 \pm 14.45$ & & $\mathrm{~F}=5.09$ \\
\hline
\end{tabular}


2) obtain a reference collection to estimate the mean size of the prey consumed.

Diet composition was expressed as a frequency of a certain prey (\%) in relation to the total number of prey consumed (numerical percentage shown as $\% N$ ) (Hyslop, 1980). Frequency of occurrence was defined as a percentage of guts containing a certain prey in relation to the total number of guts (shown as $\% F$ ) (Hyslop, 1980) and percentage of biomass $(\% B)$.

To describe prey importance in the diet of the Iberian chub, we used diagrams based on Costello's (1990) graphical method (Prenda \& Mellado, 1993), i.e. a plot of $\% N$ and $\% B$ with frequency of occurrence. The most important preys are those closer to the upper right of the graph.

We compared the diet between sexes using Spearman rank correlation coefficient, follow- ing the method described by Montañés \& Lobón-Cerviá (1986).

Shannon-Wiener diversity index (H') was applied to calculate diet diversity. Equitability (J) was calculated as the proportion $\mathrm{H}^{\prime *} 100 / \mathrm{H}^{\prime}$ max. We used values of total biomass consumed to calculate these two indexes.

A t-test was applied to compare diet diversity between sexes.

From dietary data we created a matrix of $\% N$ (columns) $\mathrm{x}$ individuals (rows) that was subjected to a principal components analysis (PCA) to illustrate the main patterns of diet variation. The two principal components found in the analysis (PC1 and PC2) were related with biometric characteristics using Pearson correlation, in order to describe patterns of diet composition of the Iberian chub.

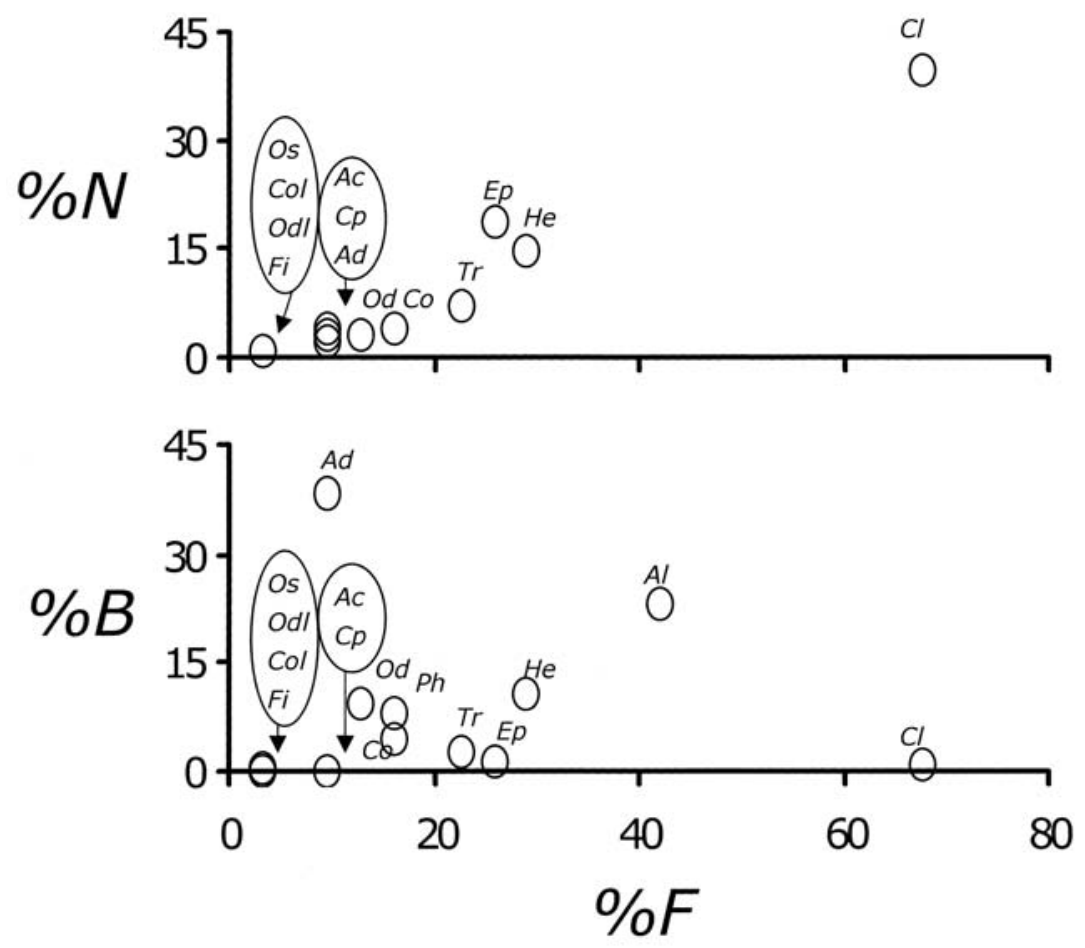

Figure 1. Relationship between numerical frequency $(\% \mathrm{~N})$ and percentage of biomass $(\% \mathrm{~B})$, with the frequency of occurrence of the food categories in chub diet. Plot based on Costello's method. Codes Al: Algae, Ph: Phanerogamae, Ad: A. desmaresti, Os: Ostracoda, Ac: Acarina, Ep: Ephemeroptera, Od: Odonata, Tr: Trichoptera, He: Heteroptera, Col: Coleoptera larvae, Co: Coleoptera, Cl: Chironomidae larvae, Cp: Chironomidae pupae, Odl: Other dipteran larvae, Fi: Fish. Relación entre la frecuencia numérica (\%N) y el porcentaje de biomasa $(\% B)$ con la frecuencia de aparición de las categorías de presa en la dieta de S. pyrenaicus. Diagrama basado en el método de Costello (1990). Códigos Al: Algae, Ph: Phanerogamae, Ad: A. desmaresti, Os: Ostracoda, Ac: Acarina, Ep: Ephemeroptera, Od: Odonata, Tr: Trichoptera, He: Heteroptera, Col: Coleoptera larvae, Co: Coleoptera, Cl: Chironomidae larvae, Cp: Chironomidae pupae, Odl: Other dipteran larvae, Fi: Peces. 


\section{RESULTS}

Of the four biometric measures, only gut length (GL) was statistically different between sexes (table 1), showing higher values for females. A strong correlation was observed between fork length and gut length $(\mathrm{r}=0.86, \mathrm{p}<0.00)$. Fork length and mouth aperture were also highly correlated $(\mathrm{r}=0.89, \mathrm{p}<0.00)$.

Fifteen types of prey were identified in chub diet. The relationship between the numerical percentage and frequency of occurrence showed that chironomid larvae was the most important prey item, however the percentage of biomass was very low (0.89\%) (Fig. 1). A. desmaresti showed the highest values of consumed biomass $(38,19 \%)$, but was not relevant in terms of frequency of occurrence and abundance $(9,68 \%$ and $2,34 \%$ respectively) (Fig. 1), since only three specimens of chub presented remains of $A$. desmaresti in their guts. On the other hand, algae were found to be a very important prey item in terms of biomass and occurrence (23,19\% and $42 \%$, respectively Fig. 1$)$.
Diet diversity was relatively low $\left(\mathrm{H}^{\prime}=\right.$ $0.48 \pm 0.36 \mathrm{sd})$, as shown by the equitability index $(\mathrm{J}=62.1 \%)$. These indexes, point out to a diet mostly based on a few basic preys and a wide group of secondary and occasional prey (Fig. 1).

Chub consumed both plant and animal material in a similar proportion. No differences were observed between mean biomass of plant material and animal material consumed per individual $(\mathrm{t}=-0.002, \mathrm{p}=0.99)$ showing that chub presents typically omnivorous feeding habits.

No differences were found between diet compositions between sexes $\left(r_{s}=0.572, p=0.001\right)$. However, diet diversity was significantly different $(t=2.20, p=0.03)$, being mean values higher for females than for males (females $\mathrm{H}=$ $0.61 \pm 0.29$; males $\mathrm{H}=0.34 \pm 0.38$ ).

No differences were found in mean prey size consumed by either sex $(\mathrm{t}=1.48, \mathrm{p}=0.15)$. A positive correlation was observed between predator size $(\mathrm{FL})$ and mean prey size $(\mathrm{r}=0.56$, $\mathrm{p}=0.001$ ). Furthermore, another positive correlation was found between mean prey size and

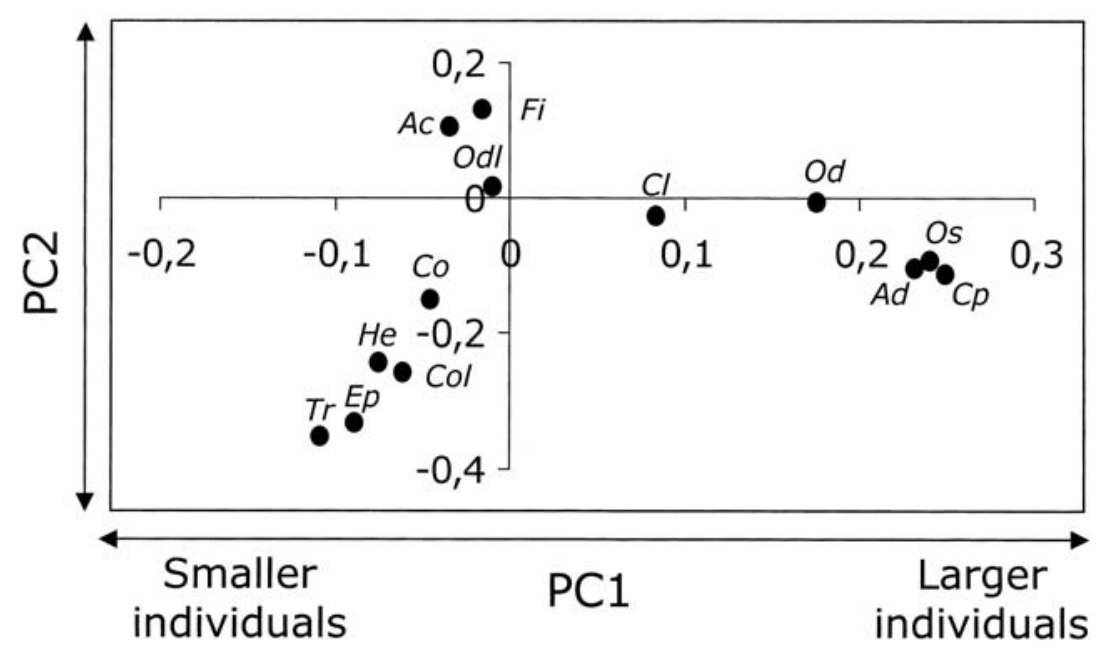

Figure 2. Distribution of each prey category in the space defined by the two first principal components generated in the principal components analysis (PCA), applied to a matrix of numerical percentage (\%N, columns) x individuals of S. pyrenaicus (rows). PC1 explains $24.10 \%$ of the total observed variance and indicates a trophic gradient variation associated to ontogenetic changes. PC2 explain $15.74 \%$ of total variance. Numerical codes are included in figure 1. Distribución de cada categoría de presa en el espacio definido por los dos primeros componentes extraídos de un análisis de componentes principales aplicado a una matriz de porcentaje numérico de cada categoría (\%N, columnas) $x$ individuos de S. pyrenaicus (filas). El PC1 explica un 24.10\% de la varianza total e indica un gradiente de variación trófica asociado a cambios ontogenéticos. El PC2 explica un 15.74\% de la varianza total. Los códigos numéricos se incluyen en la figura 1. 
mouth aperture $(r=0.45, \mathrm{p}=0.01)$. Larger individuals had larger mouths and subsequently consumed larger prey.

The first two components of the PCA globally explained close to $40 \%$ of observed variance (Fig. 2). PC1 was correlated with predator size $(\mathrm{r}=0.41, \mathrm{p}=0.01)$ and defined a gradient running from smaller specimens to larger ones. This gradient illustrated an apparent segregation in the type of prey items consumed by individuals of different size (Fig. 2). Larger individuals based their diet on $A$. desmaresti, Ostracoda and Chironomid pupae, while smaller ones consumed mainly Trichoptera, Ephemeroptera and Heteroptera.

\section{DISCUSSION}

Summer diet of S. pyrenaicus in the upper course of Yeguas stream is typical of an omnivorous feeder, since plant and animal material were consumed in a similar proportion. This is a characteristic feeding habit in fluctuating environments with seasonal food limitations (Magalhães, 1993b).

Chub diet shows a wide trophic spectrum. According to prey distribution in the stream, chubs feed at the bottom, the water column or surface habitats. Mouth position (subterminal) allows them to capture prey inhabiting benthic zones such as Chironomidae, Ephemeroptera or Trichoptera, water surface areas or pelagic ones (e.g Crustacea and Coleoptera). However, diet diversity was relatively low, based on a few basic preys. This considerable feeding plasticity was indicated for a closely related species (Leuciscus svallize) in Greece (Economou et al., 1991). Economou et al. (1991) has suggested that the broadening of the feeding spectrum allows the exploitation of a variety of alternative food resources.

An apparent change in chub diet was observed throughout ontogeny. Because the sample size was small (37 individuals), the results obtained should be taken carefully. However Magalhães (1993a) described a simi- lar pattern of chub diet, allowing us to interpret the observed ontogenetic diet shifts as follows. Size-related diet shifts are characterized by: 1) an increase in mean prey size as predator size increases, and 2) a shift in prey-type consumed by chub as individuals grow. Two factors are likely to be involved in producing this feeding pattern. First, prey use may be related to morphologic limitations in the predator. Small fishes are constrained to exploit only small prey. As they grow, morphological changes in the feeding apparatus may occur (i.e. mouth, pharyngeal teeth), allowing them to capture large prey and reducing their ability to capture small ones (Walton et al., 1992). In fact, we found a positive correlation between mean prey size consumed by chubs and mouth aperture. In addition, small fishes are able to exploit only soft-bodied prey, and as they grow, the width of the pharyngeal teeth increases (Prejs et al., 1990), so they may be able to crush hard-bodied prey.

Furthermore, other factors such as competitive interactions and prey seasonality may also be influencing these observed feeding patterns (Magalhães, 1993a). In this case, we observed a high frequency of Chironomid larvae in chub diet, mainly in large ones. Montañés \& LobónCerviá (1986) observed a similar result associated with a peak of chironomid abundance in the summer season.

No differences were found in diet composition between males and females, so both sexes showed the same trophic spectrum. However females presented a more diverse diet than males. This points out to a different feeding behaviour (and probably foraging behaviour as well) related to the avoidance of competition with males and/or to ensure the energetic demands associated with gonad production in critical periods as the summer, characterized by a reduction in food and habitat availability (Magalhães, 1993 a, b). Moreover, gut length reach higher values in females. This gut elongation in females facilitates a much more efficient digestion of plant material and detritus (Hofer, 1991), and could also be seen as a 
mechanism to reduce competition with males. In addition it could be seen as an advantage towards reproductive success, since vegetables are a more abundant and available resource than animal material during the dry season.

As in the case of ontogenetic diet shifts, the small sample size limits the validity of our assumptions related to diet diversity between sexes. More complete studies, including larger sample sizes, evaluation of seasonal variation in diet and samples of individuals with a wide range of body size, are needed to confirm our interpretation. However, results presented in this paper may be seen as a starting point for further research.

The generalist diet of chub, the apparent differences observed between sexes and the ontogenetic diet shifts may be seen as important adaptations which allow the maintenance of high fish densities in Mediterranean freshwater ecosystems, characterized by irregular climatic regimes and water flows and consequently subject to changes in trophic resources and habitat availability.

\section{ACKNOWLEDGEMENTS}

We wish to thank Prof. Emili García-Berthou and an anonymous reviewer for their constructive criticism and helpful suggestions in an earlier version of the manuscript.

\section{REFERENCES}

BELLIDO, M., J. A. HERNANDO, C. FERNÁNDEZ-DELGADO \& M. HERRERA. 1989. Alimentación de la boga del Guadiana (Chondrostoma polylepis willkommi), Stein. 1866 en la interfase río-embalse de Sierra Boyera (Córdoba. España). Doñana, Acta Vertebrata, 16(2): 189-201.

COSTELLO, M. J., 1990. Predator feeding strategy and prey importance: a new graphical analysis. $J$. Fish Biol., 18: 271-290.

COWX, I. G., W. O. YOUNG \& J. M. HELLAWELL. 1984. The influence of drought on the fish and invertebrate populations of an upland stream in Wales. Freshwater Biology 14: 165-177.

DOADRIO, I. (ed), 2001. Atlas y libro rojo de los peces continentales de España. Dirección General de Conservación de la Naturaleza. Ministerio de Medio Ambiente.

ECONOMOU, A. N., CH. DAOULAS \& P. ECONOMIDIS. 1991. Observations on the biology of Leuciscus 'svallize' in the Kremasta reservoir. Hydrobiologia, 213: 99-111.

ENCINA, L. \& C. GRANADO-LORENCIO. 1991. Diet and diel feeding chronology of three Iberian fish species. Ecology International Bulletin, 19: 43-64.

FERNÁNDEZ-DELGADO, C. \& M. HERRERA. 1995. Age structure, growth and reproduction of Leuciscus pyrenaicus in an intermittent stream in the Guadalquivir river basin, southern Spain. J. Fish Biol., 46(3): 371-380.

HOFER, R., 1991. Digestion. In: Cyprinid fishes. Systematics, Biology and Exploitation. Winfield, I. J. \& Nelson, J. S. (eds.): 413-425. Chapman \& Hall. London

HYSLOP, E. J. (1980). Stomach analysis a review of methods and their application. J. Fish. Biol., 17: 411-429.

LOBÓN-CERVIÁ, J. 1982. Ecología de la ictiofauna del río Jarama. Ph.D. Thesis, University of Madrid.

LOBÓN-CERVIÁ, J \& A. SOSTOA. 1987. El crecimiento del Cacho (Leuciscus cephalus pyrenaicus Gunther, 1862) en el río Jarama (cuenca del Tajo). Doñana Acta Vertebrata, 14: 41-51.

MAGALHÃES, M. F., 1993 a. Effects of season and body-size on the distribution and diet of the Iberian chub Leuciscus pyrenaicus in a lowland catchment. J. Fish Biol., 42: 875-888.

MAGALHÃES, M. F., 1993 b. Feeding of an Iberian stream cyprinid assemblage: seasonality of resource use in a highly variable environment. Oecologia, 96: 253-260.

MATTHEWS, W. J. 1988. North American prairie streams as systems for ecological study. J. N. Am. Benthological Soc., 7: 387-409.

MONTAÑÉS, C. \& J. LOBÓN-CERVIÁ. 1986. Feeding ecology of a population of brown trout (Salmo trutta L.) in an aquifer-fed stream of Old Castile, Spain. Ekologia Polska, 34 (2): 203-213.

PIRES, A. M., I. G. COWX \& M. M. COELHO. 1999. Seasonal changes in fish community structure of intermittent streams in the middle reaches of the Guadiana basin, Portugal. J. Fish Biol., 54: 135-249. 
PREJS, A., K. LEWANDOWSKI, \& A. STANCZYKOWSKA-PIOTROWSKA. 1990. Sizeselective predation by roach (Rutilus rutilus) on zebra mussel (Dreissena polymorpha): field studies. Oecologia, 83: 378-384.

PRENDA, J. \& E. MELLADO. 1993. Características biológicas y espectro trófico durante el otoño de dos poblaciones simpátricas de Blennius fluviatilis y Micropterus salmoides en un embalse pequeño. Limnetica 9: 107-115.

RODRÍGUEZ-JIMÉNEZ, A. J., 1987. Relaciones tróficas de una comunidad íctica, durante el estío en el río Aljucén (Extremadura, España). Misc. Zool., 11: $249-256$.
RODRÍGUEZ, J. R., 1989. Crecimiento corporal del Leuciscus cephalus pyrenaicus Gunther 1868 (Pisces, Cyprinidae) en el río Guadalhorce (Málaga, S. España). Arquivos do Museu Bocage N. Ser., 1: 311-323.

WALTON, W. E., HAIRSTON, N. G. \& WETTERER, J. K. 1992. Growth-related constraints on diet selection by sunfish. Ecology, 73: 429-437.

WINDEL, J. T. \& BOWEN, S. H. 1978. Methods for study of fish diets based on analysis of stomach contents. In: Methods for assessment of fish production in fresh water. T. Bagenal (ed.): 219-226. Blackwell Scientific Publications Oxford. 
